\title{
AN AYURVEDIC APPROACH TO A CASE OF LOW BACK PAIN (KATIGRAHA) WITH SPECIAL REFERENCE TO LUMBAR SPONDYLOSIS
}

\author{
Dr Prashant Amrutkar 1凶 iD, Dr Amruta Amrutkar $2 \square$ iD \\ ${ }^{1}$ Associate Professor and HOD, Dept of Panchakarma, B.S.D. Trust's Ayurved Mahavidyalay, \\ Wagholi, Pune, India \\ ${ }^{2}$ Assistant Professor, Dept of Samhita, B.S.D. Trust's Ayurved Mahavidyalay, Wagholi, Pune, India
}

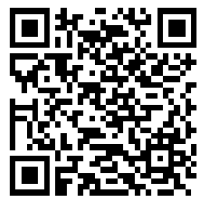

DOI: https://doi.org/10.29121/granthaalayah.v9.i1.2021.3093

Article Type: Research Article

Article Citation: Dr Prashant Amrutkar, and Dr Amruta Amrutkar. (2021). AN AYURVEDIC APPROACH TO A CASE OF LOW BACK PAIN (KATIGRAHA) WITH SPECIAL REFERENCE TO LUMBAR SPONDYLOSIS. International Journal of Research -GRANTHAALAYAH, 9(1), 158-163.

https://doi.org/10.29121/granthaa layah.v9.i1.2021.3093

Received Date: 01 January 2021

Accepted Date: 31 January 2021

Keywords:

Katigraha

Lumbar Spondylosis

Vata Vyadhi

\section{ABSTRACT}

Katigraha is a condition where the lower back region is afflicted with Vitiated Vata and present with symptoms such as pain with stiffness. Katigraha mentioned in Ayurveda can be correlated with Lumbar spondylosis due to similarity of clinical manifestations. About $60 \%$ to $80 \%$ of the population in India suffer from this condition. The current case study was carried out at the Department of Panchakarma, B.S.D. Trust's Ayurved Hospital and Research Centre,Wagholi,Pune. A 44 year male patient suffering with lumbar spondylosis was treated with samanya chikitsa of vata vyadhi i.e.Abhyanga, Swedana, Basti and Kati Basti treatment. Patient was treated for a period of 8 days. The response to the treatment was recorded and therapeutic effect was evaluated through symptomatic relief. Clinically, cardinal symptoms were significantly reduced and degree of anterior flexion increased from 40 degree to 90 degree. Radiographically, $\mathrm{X}$ Ray L.S. Spine showed an improvement in loss of lumbar lordosis. However, it still shows that the patient is suffering from lumbar spondylosis.

\section{INTRODUCTION}

Vata dosha or Sama Vata Dosha (Ama associated Vata Dosha) afflicts Kati Pradesha (low back) and produces symptoms such as pain with stiffness, then the condition is known as Katigraha.[1]

This can be correlated with lumbar spondylosis. Back pain with stiffness is the main cardinal symptom in lumbar spondylosis. This cardinal symptom is comparable with the 'Graha' condition mentioned in Ayurveda classics. Lumbosacral part of the spine is comparable with 'Kati' mentioned in ayurvedic texts. Hence, Lumbar spondylosis in contemporary medical science can be correlated with the Kati graha (one of the eighty Nanatmaja Vata Vikar) mentioned in Charak Samhita· [2]

In lumbar spondylosis, back pain is usually felt in the lumbosacral area and the back of thighs. The commonest site of pain in the spine is the intervertebral disc. Patients often complain of spinal stiffness, paraspinal muscle spasm, radiating pain to the extremities, difficulties in the activities of daily living such as sitting, walking, picking up things and so on. In chronic cases, back pain is often associated with neurological symptoms like altered sensation and

(C) 2021 The Author(s). This is an open access article distributed under the terms of the Creative Commons Attribution License, which permits unrestricted use, distribution, and reproduction in any medium, provided the original author and source are credited. 
weakness in the muscle innervated by the compressed nerve roots. Lumbar Spondylosis is a common term used to describe this degenerative condition of lumbar spine. Between 70 to 90 percent of individuals will experience back pain at some point in their lives. [3]

In this condition, both the intervertebral disc and adjacent vertebrae get involved. The intervertebral disc ages owing to proteoglycan within the disc, which becomes dehydrated as a result. Therefore, the disc becomes narrower and this in turn narrows the nerve root canal. Secondary changes also occur in the facet joints with loss of joint space, sclerosis and osteophyte formation $\cdot[4]$

In modern medicine, the disease is in early stage, it is managed by medications such as analgesics and antiinflammatory drugs, Muscle relaxants, corticosteroids, epidural steroid injections etc. but these drugs have lots of side effects and cannot be used for a long time; When symptoms are moderately severe or more, especially if it hampers the activity of patient, surgical intervention is advised. [5] So, it is the need of time to seek other treatment options mentioned in ayurveda classics.

In Ayurveda classics, low back pain-Katigraha is explained in a broad aspect under Vatavyadhi \& based on symptoms it may be correlated to Dhatu Gatawa. According to samprapti of Vatavyadhi, Katigraha is primarily caused by vitiation of Vata dosha and Asthi, Mansa, Majja dhatu kshaya. Acharya Sushruta, describes that, when vitiated Vata Dosha invades the Asthi Dhatu symtpoms like Asthi shosha, Asthi Prabheda \& Asthi Shoola are produced. (6) He also describes that, when vitiated Vata Dosha invades the Sandhi, it leads to Hanthi of Sandhi (Restriction of joint movements) \& Shopha (Muscle Spasm. [6] Therefore, Vatavyadhi Samanya chikitsa i.e., Abhyanga (Snehana), Swedana, Basti etc mentioned in ayurveda classics, was selected for the present case.[7] So, this case report is planned to evaluate the collective effect of samanya chikitsa indicated for Vata Vyadhi.

\section{MATERIALS AND METHODS}

A Case Report: Name of patient-XYZ; Age-44 Yrs/Male; Occupation-Designer (Computer Work) Long time Seating type of job; OPD Reg No 2020/2064; IPD Reg No- 2020/889; DOA-10/06/2020; DOD-17/06/2020

Brief history of a case: A 44 years old male patient, presented with the chief complaints of severe pain at low back (Katishool) and stiffness at low back (Katigraha) and other symptoms are difficult during walking and while seated (Asane- Gamane Kashtata) for 15 days. Patient had a history of frequently constipating. Complaints were worsened 3 days before the admission. He underwent allopathic treatment for the past 15 days but did get only mild and temporary relief. So, for further management he came to Panchakarma OPD, at B.S.D.Trust's Ayurved Hospital and Research Centre,Wagholi,Pune.

\subsection{DIAGNOSIS AND ASSESSMENT CRITERIA}

Lumbar spondylosis was diagnosed on the basis of following parameters. Also, these parameters were assessed before and after the treatment.

1) Pain at low back (Katishoola)- was assessed by grading of pain by using Visual Analog Scale (VAS).

$0 \mid$ 09

Table 1: Assessment and grading of pain

\begin{tabular}{|c|c|c|}
\hline PAIN (VAS) & Scale & Grade \\
\hline No Pain & 0 to 1 & 0 \\
\hline Mild, annoying pain & 2 to 3 & 1 \\
\hline Nagging, Uncomfortable, troublesome pain & 4 & 2 \\
\hline Distressing, miserable pain & 5 & 3 \\
\hline Intense, Dreadful, Horrible & 6 to 9 & 4 \\
\hline
\end{tabular}


An Ayurvedic Approach to A Case of Low Back Pain (Katigraha) With Special Reference to Lumbar Spondylosis

On the day of admission, the patient was in distressing, miserable pain with a VAS Score of 5.

2) Stiffness at low back (Katigraha)- was assessed by grading of Range of Motion (ROM) by using the Oswestry Disability Index (ODI)

Table 2: Assessment and grading of stiffness

\begin{tabular}{|c|c|}
\hline Stiffness (ROM) & Grade \\
\hline No stiffness & 0 \\
\hline With upto $25 \%$ impairment in ROM of joint and patient can perform daily work without any difficulty & 1 \\
\hline $\begin{array}{l}\text { With upto } 25 \%-50 \% \text { impairment in ROM of joint and patient can perform daily work with mild or } \\
\text { moderate difficulty }\end{array}$ & 2 \\
\hline $\begin{array}{c}\text { With upto } 50 \%-75 \% \text { impairment in ROM of joint and patient can perform daily work with moderate or } \\
\text { severe difficulty }\end{array}$ & 3 \\
\hline $\begin{array}{c}\text { With more than } 75 \% \text { impairment in ROM of joint and patient totally unable to perform daily routine } \\
\text { work }\end{array}$ & 4 \\
\hline
\end{tabular}

On the day of admission, the range of movements were restricted, the patient was with upto 50\%-75\% impairment in Range of motion of joint and patient can perform daily work with moderate or severe difficulty i.e., Grade 3; on the day of admission oswestry disability index was 25 points/50 percent.

3) Investigation: X-ray of Lumbosacral Spine (AP/ LAT Views) was assessed during and after treatment. Xray of Lumbosacral Spine (12/06/2020) revealed lumbar spondylosis. Muscle spasm with loss of lumbar lordosis seen. Also, minimally reduced L5-S1 Disc space seen. Tiny anterio-lateral osteophytes at L4-L5 Vertebral levels-degenerative changes were noted.

4) Clinical examination: Difficulty in Straight Leg Rising (SLR) i.e., anterior flexion was assessed before and after treatment. At the time of admission, clinical examination revealed tenderness in the lumbar region. The SLR test was positive 40 degrees at left and 45 degrees at right. The range of movements

\section{Treatment given-Following treatment was given for 8 days}

1) Kati basti- Kati basti with Mahanarayana Thailam for 20 min was given daily for 8 days.

2) Sarvanga Abhyanga with Mahanarayana Thailam for 30 minutes daily for 8 days followed by

3) Bashpa Sweda with decoction of Ashwagandha.

4) Matra Basti- Matra basti of $60 \mathrm{ml}$ each was given for 6 days out of the total 8 days of treatment. Each 60 $\mathrm{ml}$ of matra basti was consists of Mahanarayana Tail $30 \mathrm{ml}+$ Chinchalavan Tail $30 \mathrm{ml}$; Matrabasti was given after lunch at $12: 30 \mathrm{pm}$

5) Niruha Basti- The preparation of niruha basti was done in the usual manner of Niruha Basti. Madhu 30 $\mathrm{ml}$ added together with saidhav 5 gms, mixed well; then $50 \mathrm{ml}$ of Tila Tailam was added with the previous mixture. Lastly, decoction of $400 \mathrm{ml}$ of Panchatikta Kashay was added to it. The mixture is then filtered through a sieve. Niruha basti was given on empty stomach at morning 07:30 am

Matra basti and Niruha basti were administered as follows.

\begin{tabular}{|c|c|c|c|c|c|c|c|c|}
\hline Day & 1 & 2 & 3 & 4 & 5 & 6 & 7 & 8 \\
\hline Basti & M & M & M & M & N & M & N & M \\
\hline
\end{tabular}

M: Matrabasti; N: Niruha Basti

Out of 8 days of treatment- total 6 Matra basti and 2 Niruha basti were administered. 


\section{RESULTS}

Results of the treatment were observed on the basis of following parameters as follows.

Table 3: Results of the treatment

\begin{tabular}{|c|c|c|c|}
\hline \multirow[t]{2}{*}{ Parameter } & \multicolumn{2}{|c|}{ Observation } & \multirow{2}{*}{$\begin{array}{c}\text { Improvement } \\
\%\end{array}$} \\
\hline & $\mathrm{BT}$ & $\mathrm{AT}$ & \\
\hline VAS Score (PAIN) & 5 & 1 & $80 \%$ \\
\hline $\begin{array}{l}\text { ROM Grade } \\
\text { (STIFFNESS) }\end{array}$ & 3 & 1 & $66 \%$ \\
\hline ODI & 25 Points & 6 Points & $76 \%$ \\
\hline SLR & $\begin{array}{l}\text { RT-45 Degree } \\
\text { LT- } 40 \text { Degree } \\
\text { B/L- } 40 \text { Degree }\end{array}$ & $\begin{array}{l}\text { RT-90 Degree } \\
\text { LT- } 80 \text { Degree } \\
\text { B/L- } 80 \text { Degree }\end{array}$ & \\
\hline X-ray & $\begin{array}{l}\text { Loss of lumbar lordosis seen; } \\
\text { Lumbar spondylosis mild changes }\end{array}$ & $\begin{array}{l}\text { Mild loss of lumbar lordosis seen; } \\
\text { Lumbar spondylosis mild changes }\end{array}$ & \\
\hline
\end{tabular}

BT-Before treatment; AT-After treatment; ODI-Oswestry Disability index

Table 3 shows that the patient found significant relief in symptoms after the treatment. Lower back Pain was reduced by $80 \%$ (from VAS Score 5 to 1); Stiffness was reduced by $66 \%$ (from ROM Grade 3 to 1) With upto 25\% impairment in ROM of joint and patient can perform daily work without any difficulty. SLR Test in B/L legs was increased to 80 degrees from 40 degrees.Oswestry Disability Index was improved by $76 \%$ from 25 Points to 6 Points.

\section{DISCUSSION}

In the present case of lumbar spondylosis, the patient was affected more with Katigraha might be because he has to do more prolonged seating type of work (Occupation-Computer work designer). Prolonged sitting posture exerts pressure over low back and provides favourable condition for lodging (Sthana Samsharaya) of already vitiated Vata Dosha. Patient's age showed that, above 40 years of age, degenerative changes start that leads to Vitiated Vata Dosha disorders.

In Ayurveda classics, most of the joint pain related conditions have been explained under the heading of Vatavyadhi. Katigraha is comparable with the clinical manifestation of Lumbar Spondylosis. Katigraha is one of the eighty Nanatmaja Vata Vikara mentioned in Ayurveda classics. So, this present case of lumbar spondylosis was treated with Samanya Chikitsa of Vatavyadhi including Sarvanga Abhyanga, Bashpasweda, Katibasti and Basti.

\section{Probable mode of action of Samanya Chikitsa of Vatavyadhi}

Sarvanga Abhyanga is a type of Bahya Snehana. Acharya Dalhana explains that the drugs and oil used in Abhyanga gets absorbed by the skin, reaching to particular Dhatu when applied for sufficient time. Hence it is clear that drugs used in the abhanga get absorbed by the skin; it prevents and corrects disorders caused by affliction of vata.

Bashpa Sweda is Sagni prakara of Sweda. Acharya chakrapani has stated that stambha also means obstruction or block. Therefore, Swedana not only relieves stiffness, but also clears blockage of passages. Snigdha Sweda pacifies vata dosha and relieves stiffness.

Katibasti was the procedure selected for local application as Kati is the most probable region afflicted in this condition.Kati Basti is a snigdha, saagni type of swedana which by its local effect helps in relieving Stambha, Shaityata 
and helps in relieving intensity of pain and stiffness. It may help in immediate relief of symptoms causing an analgesic effect. The lipoidal bond is suitable for penetration of drug molecules through stratum corneum[8]. On this basis, it can be assumed that, in Katibasti oil helps in the formation of lipoidal bonds thus helps in penetration of drug molecules. Katibasti is a type of Swedana, so it induces hyperthermia which improves local blood and lymphatic circulation and thereby improving local tissue metabolism[9]. It reduces inflammation by modifying secretions of various inflammatory mediators, relaxes local musculature by physical effect of heat, increases the rate of transdermal drug delivery and thereby reduces pain [10]

Basti Chikitsa is considered as an Ardha Chikitsa (half line of treatment)[11] and Shrestha Chikitsa for pacifying aggravated Vata. So, it is highly recommended and useful treatment in Vitiated Vata disorders. Acharya Sushruta explains the mode of action of Basti saying that, Basti given through rectal route gets absorbed and shows its effects all over the body just like the water gets absorbed through the roots and nourishes the whole plant.

Considering overall effects of Samanya Chikitsa of Vatavyadhi including Sarvanga Abhyanga, Bashpasweda, Katibasti and Basti was highly effective in this present case of Lumbar Spondylosis.

\section{CONCLUSION}

Patient of low back pain (Katigraha) diagnosed as Lumbar Spondylosis was treated with Samanya Chikitsa of Vatavyadhi including Sarvanga Abhyanga, Bashpasweda, Katibasti and Basti. Overall, collective effects of Samanya Chikitsa of Vatavyadhi showed highly effective results in this present case. Patient had better effect in relieving pain, stiffness and Oswestry Disability Index (ODI) change with Panchakarma therapy. Thus it can be concluded that Ayurvedic approach is better, safe and effective treatment as compared with contemporary approach in treating painful spinal conditions. This study needs further evaluation on large numbers of patients.

\section{SOURCES OF FUNDING}

This research received no specific grant from any funding agency in the public, commercial, or not-for-profit sectors.

\section{CONFLICT OF INTEREST}

The author have declared that no competing interests exist.

\section{ACKNOWLEDGMENT}

None.

\section{REFERENCES}

[1] Bramhashankara M, editor BhavaPrakash of Bhava Mishra. Ch 26. Ver 53, Part 2. 12th Edition Varanasi Chaukhaamba Sanskrit Sansthan 2016. Page No 292

[2] Brambhanand Tripathi. Charak Samhita sutrasthan; Chaukhambha Surbharati Prakashan; 2013 Page No 389390; Shlok 20/11

[3] Short Practice of Surgery: Bailey and Love; 23rd Edition; chapter 33; Page No. 518-521

[4] Short Practice of Surgery: Bailey and Love; 23rd Edition; chapter 33; Page No. 514-518

[5] J Maheshwari, Essential orthopaedics, Jaypee brothers, medical publisher (p) ltd, 2011, page 277

[6] Srikantha Murthy, Sushrut Samhita, Vol 1 Chaukhambha Orientalia, Varanasi 2010, pg 464-465

[7] Srikantha Murthy, Sushrut Samhita, Chikitsa sthan, Vol 2 Chaukhambha Orientalia, Varanasi 2017, pg 59

[8] Namjoshi P V, Abhinav; possible scientific reasons behind the supportive actions of sthanik snehana and swedana. Pharma Sci Monit 2015; 6:110-8

[9] Shirota H, Goto M, Katayama K, application of adjuvant induced local hyperthermia for evaluation of antiinflammatory drugs; J Pharmacol Exp Ther 1988;247;1158-63 
[10] Brosseau L, Young KA, Robinson V, Merchand S et al. Thermotherapy for treatment of osteoarthritis. Cochrane Database Syst Rev 2003;4; CD004522

[11] Charak samhita Vol 2; Vidyadhar Shukla Chaukhambha Sanskrit Pratishthan Shlok Ch.Si 1/39. 